\title{
A note on the rediscovery of the Sokoke Pipit Anthus sokokensis in the Pugu Hills, Tanzania
}

C. O. F. MLINGWA

The Sokoke Pipit Anthus sokokensis is endemic to coastal forests in Kenya and Tanzania (Keith et al. 1992). It has been listed as occurring in the Pugu Hills, Tanzania (Howell 1981, Collar and Stuart 1985, 1988), having been first recorded in 1938 (Moreau 1940). Two further records from this area are reported in Collar and Stuart (1985), in 1955 and 1981. Harvey and Howell (1987) noted that, over the period 1968-1978, many visits to the area by a variety of observers, some using mist-nets, failed to locate Sokoke Pipit.

During the period from June 1994 to May 1995 bird-ringing was carried out in the Pugu Forest Reserve at three localities. Site 1 was in a thicket located south of Minaki High School, site 2 was in natural forest near the water reservoir and site 3 was in secondary forest dominated by exotic Cassia siamea. Each site was mist-netted for about one week in every month, using between 10 and 22 mist-nets.

On 29 October 1994 at 08 hoo (local time), one adult Sokoke Pipit was caught in the thicket (site 1). The bird, which was in good plumage without any sign of breeding, was weighed, measured, ringed and released.

The vegetation characteristics of the net line were (mean \pm S.D., $n=21$ : shrub height $3.1 \pm 1.1 \mathrm{~m}$ (range $2.0-5.5 \mathrm{~m}$ ), shrub density $65.9 \pm 21.8 \%$ (range $10-85 \%$ ) and ground cover $26.2 \pm 17.9 \%$ (range $5-70 \%$ ). The common plants in the study area were Diospyros sp., Landolphia kirkii, Milletia puguensis, Salacia madagascariensis, Serugada sansibariensis, Synaptolepis kirkii, Uvaria acuminata, Cyperus sp. and Panicum trichocladum.

It is clear that the Sokoke Pipit still occurs in the Pugu Hills but is very rare. The situation is similar to recent observations in nearby areas at Vikindu (Mlingwa 1991, 1993) and Dondwe (S. Davies pers. comm. 1994, Collar et al. 1994).

In the Sokoke Forest, Kenya, the Sokoke Pipit is common in dense uncleared forest, though earlier reports suggested that it preferred forest edges and glades (Collar and Stuart 1985). As with the 1994 bird, the earlier records from the Pugu Hills were on the edge of thickets, which were considered to be relicts of the original scrubby forest (Collar and Stuart 1985).

Pugu Forest Reserve, $22 \mathrm{~km}^{2}$ in area, has less than $10 \mathrm{~km}^{2}$ of natural forest, the remaining vegetation being thickets and plantations of Cassia siamea and Eucalyptus spp. Thickets also extend outside the reserve boundary.

Further work is required to elucidate the species's status and habitat preferences in the area. 


\section{Acknowledgements}

I am very grateful to the Deutscher Akademischer Austauschdienst, the Institut für Vogelforschung in Wilhelmshaven, Germany, and the GEF Biodiversity Project in Tanzania for sponsoring the study in the Pugu Forest Reserve. I also thank F. Kashamba and G. Baitwa for their assistance in the field. A permit to work in the reserve was given by the office of Natural Resources, Coast Region, for which I am indebted.

\section{References}

Collar, N. J., Crosby, M. J. and Stattersfield, A. J. (1994) Birds to Watch 2: the world list of threatened birds. Cambridge: BirdLife International (BirdLife Conserv. Ser. No. 4).

Collar, N. J. and Stuart, S. N. (1985) Threatened birds of Africa and related islands: the ICBP/ IUCN Red Data Book. Cambridge: International Council for Bird Preservation.

Collar, N. J. and Stuart, S. N. (1988) Key forests for threatened birds in Africa. Cambridge: International Council for Bird Preservation (Monogr. No. 3).

Harvey, W. G. and Howell, K. M. (1987) Birds of the Dar es Salaam area, Tanzania. Gerfaut 77: 205-258.

Howell, K. M. (1981) Pugu Forest Reserve: biological values and development. African. J. Ecol. 19: 73-81.

Keith, S., Urban, E. K. and Fry, C. H. (1992) The birds of Africa, 4. London: Academic Press.

Mlingwa, C. (1991) Further records of the Sokoke Pipit Anthus sokokensis from Tanzania. Scopus 15: 57-58.

Mlingwa, C. O. F. (1993) Vikindu Forest Reserve, Tanzania: a first ornithological survey including a record of the Sokoke Pipit Anthus sokokensis. Scopus 17: 8-13.

Moreau, R. E. (1940) Distributional notes on East African birds. Ibis 14(4): 454-463.

C. O. F. MLINGWA

Department of Zoology, University of Dar es Salaam, P. O. Box 35064, Dar es Salaam, Tanzania.

Current address: Institut für Vogelforschung, An der Vogelwarte 21, 26386 Wilhelmshaven, Germany. 